\title{
KEBIJAKAN EKONOMI INDONESIA DITINJAU DARI KONSEP DASAR EKONOMI ISLAM
}

\author{
Oleh: Yulia Hafizah
}

\section{Abstract}

This paper aims to picture the Indonesia economy policy in perspective of Islamic economy concept. First, the writer describe historically the relation between economy and politic which then present the world economy systems. In Indonesia context, the system of economy which formulated was different with the other world economy system such as liberalism and mercantilism. The system economy of Indonesia, known as the Pancasila economy system stand between both of them. According to the writer, the Indonesia economy system has the same goal with the basic concept of Islamic economy that to create the social justice. The problem is that the basic concept of Indonesia economy often had the multi-faces when implementated in the reality.

استهلف البحث إلن تسجيل سياسة الإقتصاد ين إندونيسيا من منظور المفاهيم

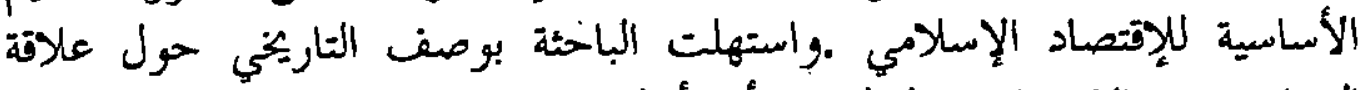

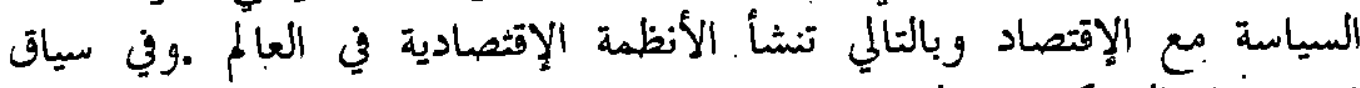

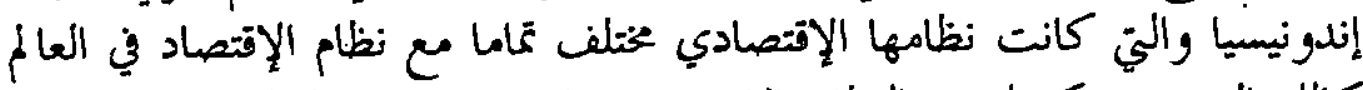

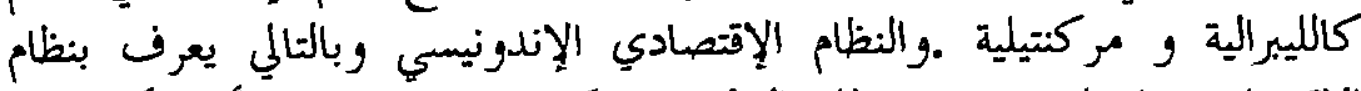

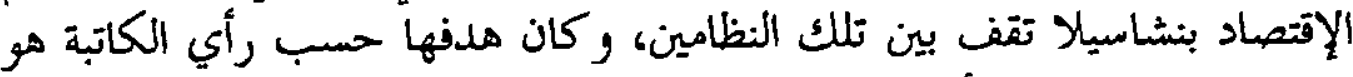

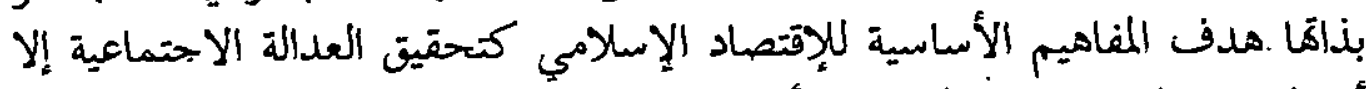

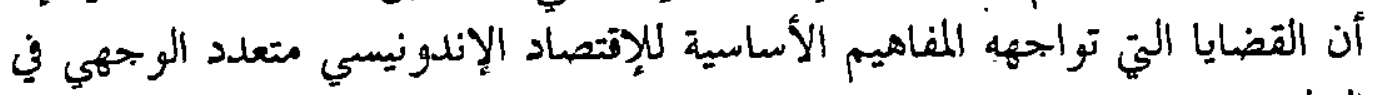

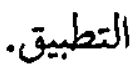

Kata kunci: politik ekonomi, ekonomi Indonesia, sistem ekonomi Islam 


\section{A. Pendahuluan}

Sejak dahulu sampai sekarang, praktek politik tidak bisa dilepaskan begitu saja dengan ekonomi. Kehidupan politik dan ekonomi selalu saling bertemu, saling mempengaruhi dan jalin-menjalin. Aktivitas-aktivitas politik karena itu amat sulit dipisahkan dari aktivitas-aktivitas ekonomi.

Dalam setiap tindakan politik ada aspek ekonominya, demikian pula struktur perekonomian suatu masyarakat dapat mempengaruhi lembaga-lembaga politik, baik yang sudah ada maupun yang akan ada di kemudian hari. Joseph Crosey yang mengadakan penyelidikan khusus dan mendalam tentang hubungan ilmu politik dan ekonomi, seperti yang dikutip oleh Isjwara mengatakan: “That politics and economic life have much to do with each other as remark matched in self evidence only by the parallel observation that politic science and economics are of mutual interest". ${ }^{1}$

Orang-orang Yunani menciptakan istilah "oikonomos" yang berarti urusan rumah tangga, sejak itu pula kehidupan politik tidak terlepas darinya. Namun istilah tersebut tidak hanya dipergunakan dalam arti yang sempit—mengenai pengelolaan rumah tangga saja - tetapi juga dipergunakan dalam arti luas, menyangkut pengelolaan negara kota. Karena negara kota itu disebut dengan negara polis, maka istilah political economy sudah digunakan. ${ }^{2}$ Istilah tersebut mengandung pengertian bahwa dalam sebuah masyarakat ekonomi, keterlibatan pemerintah di dalamnya memang tidak dapat dinafikan.

\section{B. Sekitar Kebijakan Ekonomi}

Sampai abad ke-17 M., keterlibatan pemerintah dalam bidang perekonomian dapat ditelusuri dari adanya usaha negara Spanyol dalam membiayai penjelajahan Columbus untuk menemukan jalan terpendek dari Eropa ke India. Berhasilnya penemuan tersebut mengakibatkan dorongan yang luar biasa kepada negara-negara Eropa untuk berlombalomba mengejar kekayaan, salah satunya dengan menjajah negara-negara di Asia yang mereka temukan. Dari sini kemudian berkembang sebuah aliran atau paham ekonomi Merkantilis (negara merupakan faktor positif" pemimpin" dalam perekonomian). ${ }^{3}$

'F. Isjwara, 1989, Pengantar Ilmu Politik, Semarang: Putra Bardin, hal. 74.

${ }^{2}$ George Soule, 1994, Pemikiran Para Pakar Ekonomi Terkemuka dari Aristoteles Hingga Keynes, ter. Gilarso, Yogyakarta: Kanisius, hal. 10.

${ }^{3}$ Merkantilisme merupakan sebuah julukan yang diberikan oleh para pengkritik paham ini terutama Adam Smith. Tetapi julukan ini sama sekali tidak dipakai oleh para penganutnya. Mereka tidak menganggap dirinya sebagai mazhab atau aliran ekonomi tersendiri, apalagi berpretensi untuk menyusun sebuah kerangka berpikir ilmiah. Mereka adalah orang-orang lapangan, praktisi, baik sebagai pedagang maupun politikus. Namun dalam arti tertentu, julukan merkantilisme memang tepat digunakan karena sebutan tersebut mengandung makna menyamakan kebijakan suatu bangsa atau negara dengan kebijakan seorang pedagang yang berusaha mendapatkan hasil yang lebih besar saat menjual dibandingkan dengan apa yang dikeluarkan saat membeli. Seperti layaknya 
Politik perekoniomian merkantilisme sebagai aliran perekonomian bertujuan untuk memperkuat negara dengan jalan akumulasi kekayaan atau kapital, karena itu pembangunan ekonomi harus diprioritaskan. Kalau upaya akumulasi itu tidak cukup dilakukan di dalam negeri, perdagangan internasional harus digalakkan sebagai sarana perjuangan mencapai kepentingan nasional, yaitu akumulasi kapital. Demi memperoleh surplus sebanyak mungkin dari perdagangan internasional dalam lingkungan yang penuh konflik, pemerintah dalam masing-masing negara harus mengembangkan kebijaksanaan "nasionalis-ekonomi" yaitu dengan: pertama, menerapkan pengendalian harga dan upah buruh sehingga barang yang dihasilkan bisa dijual dengan harga yang bersaing di pasar internasional; kedua, menerapkan strategi industrialisasi substitusi impor; ketiga, menggalakkan ekspor barang manufaktur dan membatasi impor hanya untuk komoditi pasar. ${ }^{4}$

Dalam abad ke-18, lahirlah di Eropa stelsel perekonomian baru yang didasarkan atas ajaran Quesnay di Perancis dengan aliran phisiokratnya dan Adam Smith di Inggris dengan aliran klasiknya yang membuka aliran perekonomian liberal. Stelsel perekonomian ini berbeda sekali dengan stelsel perekonomian merkantilisme. Jika dalam stelsel perekonomian merkantilisme negara memainkan peran positifdalam bidang perekonomian dan secara langsung turut campur tangan dalam jalannya perekonomian, maka sebaliknya aliran liberalisme justru tidakmenghendaki campur tangan negara dalam bidang ini. Negara harus membiarkan individu masing-masing mencari kesejahteraannya, berusaha dan berekonomi dengan sebebas-bebasnya dalam ekonomi domestik maupun internasional. Dengan kata lain mereka menganjurkan pasar bebas. ${ }^{5}$

Selanjutnya, pada akhir Perang Dunia I di Inggris dikemukakan ide-ide tentang "Negara Kesejahteraan" (welfare state), antara lain oleh pelopor-pelopor "Fabian Society", 6 sebagai akibat dari tidak terjadinya keseimbangan dalam pemenuhan lapangan

pedagang, bangsa yang merkantilis memandang bangsa lain sebagai saingannya dengan cara monopoli dan lain-lain. Demikian pula halnya mereka memperlakukan negara-negara jajahannya, menguras sumber-sumber daya yang murah dan mengupahnya dengan upah yang rendah. Lihat Ibid., hal. 33.

${ }^{4}$ Mochtar Mas'oed, 1994, Ekonomi Politik Internasional dan Pembangunan, Yogyakarta: Pustaka Pelajar, hal. 20.

${ }^{5}$ Kaum liberal ini berasumsi bahwa individu (konsumen, perusahaan dan wiraswasta individual) adalah aktor utama dan mereka berperilaku rasional dan selalu berusaha memaksimalkan perolehan. Tindakan rasional adalah tindakan yang didasarkan kepada kalkulasi untung-rugi atas berbagai kemungkinan pilihan. Kaum liberal juga meyakini bahwa sebenarnya tidak ada alasan untuk timbulnya konflik dalam hubungan ekonomi-politik. Jadi kalau perdagangạn dibebaskan dari peraturan pemerintah, setiap aktor yang terlibat akan bisa memperoleh keuntungan sesuai dengan barang dan jasa yang tersedia. Dengan demikian kesejahteraan akan meningkat. Ibid, hal. 22-23.

${ }^{6} \mathrm{~F}$. Isjwara, Pengantar Ilmu Politik, hal. 77 
pekerjaan (full employment) dari politik ekonomi liberalis. Pada waktu itu walaupun pasar telah mencapai keseimbangan makro ekonomi, namun di sisi lain telah banyak menimbulkan dampak pengangguran dan hal ini merupakan sumber kemiskinan. Dalam situasi tersebut, penciptaan lapangan pekerjaan tidak bisa dilakukan lagi oleh pasar. Karena itu negara harus turun tangan untuk melakukan investasi, bahkan investasi-investasi besar untuk menciptakan proyek berskala besar guna menciptakan kesempatan kerja. Dengan investasi tersebut, mekanisme pasar kembali pulih. ${ }^{7}$

Dalam suatu negara kesejahteraan, negara mempunyai tugas politik dalam semua sektor kehidupan, terutama dalam sektor perekonomian. Tugas negara dalam menciptakan kesejahteraan tidak terbatas pada suatu golongan tertentu dalam masyarakat, tetapi adalah untuk semua warganegara dan tidak pula untuk suatu waktu dalam kehidupan individu, dimulai dari dilahirkan sampai meninggal. Negara harus memperhatikan kesejahteraan individu dan masyarakat tersebut dan inilah yang dinamakan universalisme negara kesejahteraan. Seiring dengan lahirnya konsepsi negara kesejahteraan ini, timbul. pula apa yang dinamakan "konsepsi ekonomi kesejahteraan" yang memberikan dasardasar teoritis ekonomis kepada konsepsi negara kesejahteraan itu. ${ }^{8}$

Dari sini kita kembali melihat, bahwa negara memainkan peranan positif dan konstruktif dalam semua bidang, terutama dalam sektor perekonomian. Campur tangan negara dalam sektor perekonomian yang vital dapat dipandang sebagai salah satu ciri dari perekonomian abad kedua puluh satu ini.

\section{Kebijakan Dasar Ekonomi Indonesia}

Di Indonesia, keterlibatan negara bidang ekonomi bisa dilihat dari politik "ekonomi terpimpin" yang dijalankan. Landasan konseptual bagi ekonomi terpimpin ini tercantum dalam UUD 1945 Pasal 33 ayat 1, 2, 3, dan 4 yang menyatakan bahwa "Perekonomian disusun sebagai usaha bersama berdasar asas kekeluargaan" (ayat 1). "Cabang-cabang produksi yang penting bagi negara dan yang menguasai hajat hidup orang banyak dikuasai oleh negara" (ayat 2). "Bumi dan air dan kekayaan alam yang terkandung di dalamnya dikuasai oleh negara dan dipergunakan untuk sebesar-besarnya kemakmuran rakyat" (ayat 3). "Perekonoman nasional diselenggarakan berdasar atas demokrasi ekonomi dengan prinsip kebersamaan, efisiensi keadilan, berkelanjutan, berwawasan lingkungan, . kemandirian serta dengan menjaga keseimbangan kemajuan dan kesatuan ekonomi nasional" (ayat 4). Dengan landasan konstitusional ini pemerintah telah menyatakan bahwa berbagai cabang-cabang produksi sebagai milik bersama rakyat. ${ }^{9}$

7M. Dawam Rahardjo, "Peran Negara dalam Proses Demokrasi Ekonomi" dalam Jurnal Reformasi Ekonomi, No. 1 Januari-April 2001, hal. 19.

${ }^{8} \mathrm{~F}$. Isjwara, Pengantor, hal. 77

${ }^{9}$ Undang-Undang Dasar Republik Indonesia Tahun 1945, 2002, Bandung: Citra Umbara. 
Pada masa pemerintahan Soekarno, manifestasi ekonomi terpimpin ini diwujudkan dengan "politiksebagai panglima" dan memandang masalah-masalah ekonomi sebagai hal yang kurang penting dibanding dengan kampanye militer. Pengabaian masalahmasalah ekonomi ini kemudian membuat ekonomi Indonesia nyaris ambruk. Operasioperasi militer melawan pemberontakan di Sumatera dan Sulawesi selama krisis 19571958, memaksa pemerintah mengambil jalan menempuh anggaran defisit yang sangat besar. Masalah anggaran defisit ini kemudian diperburuk oleh adanya pembangunan militer untuk mendukung kampanye Irian Barat dan "Ganyang Malaysia". Kalau pada tahun 1955 defisit itu hanya 14 persen dari pendapatan pemerintah, maka pada tahun 1965 meningkat menjadi 174 persen. $^{10}$

Defisit besar itu mendorong laju inflasi. Akan tetapi, bukannya hal ini langsung diatasi, pemerintah malah meningkatkan biaya-biaya militer. Ditambah lagi hutang Indonesia di luar negeri. Demokrasi Terpimpin menciptakan hutang luar negeri yang berjumlah $\$ 2.358$ juta. Di arena internasional, Indonesia semakin dikucilkan, ketika Indonesia dikeluarkan dari keanggotaan PBB dan IMF tahun 1965. Kemudian berencana untuk mendirikan organisasi kerjasama internasional yang hanya beranggotakan negara-negara nonimperialis, yaitu The Conference of The New Emerging Force (CONEFO). ${ }^{.1}$

Dengan kondisi ekonomi yang semakin parah ditambah dengan kemelut politik yang ditandai dengan konflik-konflik terbuka antara Angkatan Darat, umat Islam dan PKI, mengharuskan Soekarno turun dari pemerintahan Demokrasi Terpimpinnya dan berakhirlah masa Orde Lama.

Bersamaan dengan runtuhnya rezim Soekarno, hilanglah slogan "politik sebagai panglima" yang dicanangkan oleh para pendukung rezim tersebut dan muncullah slogan baru "ekonomi sebagai panglima" yang diciptakan oleh para pembuat pendapat umum yang sebelumnya ditindas oleh rezim tersebut.

Slogan tersebut temyata mampu menarik hati masyarakat luas yang merindukan perbaikan kondisi ekonomi. Penelitian yang dilakukan para intelektual ekonomi dan hasil diagnosa mereka, menyatakan bahwa faktor utama yang harus diatasi adalah masalah keuangan. Untuk mengembalikan keadaan ekonomi ke keadaan ekuilibriumnya, yaitu menstabilkannya, pemerintah Orde Baru perlu menyediakan bahan-bahan pokok seperti beras, tekstil dan penyediaan suku-cadang serta bahan-bahan mentah. Untuk keperluan ini pemerintah kemudian melakukan pinjaman ke luar negeri seperti Jepang dan negaranegara Barat.

\footnotetext{
${ }^{10}$ Mochtar Mas'oed, 1989, Ekonomi dan Struktur Politik Orde Baru 1966-1971, Jakarta: LP3ES, hal. 47.
}

- "Ibid. hal. 48. 
Berbagai diplomasi ke luar negeri dilakukan untuk menarik minat investor asing menanamkan modal di Indonesia. Suatu pekerjaan yang tidak gampang, mengingat pada masa Soekarno, hubungan Indonesia dengan luar negeri tidak baik. Kerja keras ini akhirnya mendatangkan hasil dengan dijalinnya hubungan dengan IGGI (Inter Govermental Group of Indonesia) tahun 1967 dan sejak itu berfungsi sebagai sumber terbesar bantuan asing di Indonesia. ${ }^{12}$

Yakin akan keadaan yang menguntungkan ini, Indonesia kemudian melaksanakan pembangunan jangka panjang tahap pertama (PJPT I) dengan rencana pembangunan lima tahun (Repelita) yang dimulai pada tanggal 1 April 1969 dengan melaksanakan Pelita I, lima tahun kemudian II, III, IV dan V dan berencana untuk melanjutkan ke PJPT II (Indonesia tinggal landas). Sedemikian rupa rencana pembangunan yang diprogram oleh rezim ini, ternyata belum dapat menyelesaikan masalah-masalah ekonomi. Bahkan menurut catatan Liddle, beberapa masalah dasar ekonomi seperti pengangguran, kebangkrutan bisnis pribumi, gejala pengusaha-klien dan birokrasi semakin menjadi lebih gawat. ${ }^{13}$ Bahkan dapat dikatakan sebagian besar masalah tersebut, akhirnya mengharuskan Soeharto turun dari puncak kepemimpinannya sebagai Presiden di masa Orde Baru pada akhir Mei 1998. ${ }^{14}$

Segera tampuk kepemimpinan beralih ke B.J. Habibie yang pada masa sebelumnya berkedudukan sebagai Wakil Presiden. Dimulailah era Reformasi. Dari periode pemerintahan transisi pasca Orde Baru ini ada dua fenomena yang cukup menarik untuk disoroti. Pertama, revitalisasi strategi perjuangan umat Islam melalui gelanggang politik partisan. Dalam kurun waktu kurang dari enam bulan, telah dideklarasikan pendirian lebih dari 80 partai dan sekitar hampir separuh adalah partai-partai yang berbasiskan Islam. Dengan demikian gagasan artikulasi kepentingan umat Islam melalui parta politik agaknya sedang mendapatkan tempat yang luas seiring dengan perubahan pada sistem politik. ${ }^{\text {Is }}$ Kedua, munculnya perdebatan sekitar konsep ekonomi kerakyatan di sponsori Adi Sasono untuk mendukung perusahaan-perusahaan kecil, menengah dan koperasi-koperasi. Secara implisit, ini diterjemahkan untuk membantu perusahaanperusahaan pribumi. ${ }^{16}$

${ }^{12}$ Lihat M.J. Kasiyanto, 1999, Masalah Sospol Dalam Pembangunan, Kharismatik, Fundamentalis, Revolusi Gagal Membangun, Jakarta: Tri Mawar, hal. 178-181.

${ }^{13}$ R. William Lidlle, "Regime: The New Order" dalam Donald K. Emmerson (ed.), 2001, Indonesia Beyond Soeharto: Polity Economy Society Transition, New York: ME. Sharpe, hal. 4952 .

${ }^{14}$ Lihat Aminuddin, 1999, Kekuatan Islam dan Pergulatan Kekuasaan di Indonesia Sebelum dan Sesudah Runtuhnya Rezim Soeharto, Yogyakarta: Pustaka Pelajar, hal. 360-361.

${ }^{15}$ Lihat Ibid., hal. 372-373.

${ }^{16} \mathrm{Hal}$ Hill, 2001, Ekonomi Indonesia, ter. Tri Wibowo Budi Santoso, Jakarta: Rajagrafindo Persada, hal. 374 . 


\section{Landasan Kebijakan Ekonomi Indonesia}

Secara konseptual, sistem (kebijakan) ekonomi Indonesia berbeda, baik dengan liberalisme maupun merkantilisme. Dalam sistem liberalis, hak milik perseorang (property right) diakui dan dilindungi. Selanjutnya alokasi sumber daya tidak ditentukan oleh negara, melainkan diserahkan kepada tangan-tangan gaib (invisible hand), yaitu mekanisme pasar. Negara adalah visible hand yang peranannya bisa mendistorsi pasar dan karena itu harus dibatasi seminimal mungkin. ${ }^{17}$ Sebaliknya dalam merkantilis, negara memegang peranan yang sangat dominan dalam menentukan segala aturan main dalam pengembangan sumber daya dan distribusinya. Negara berkuasa mutlak dalam menetapkan segalagalanya baik dalam pemilikan, penguasaan maupun pemanfaatan faktor-faktor produksi. ${ }^{18}$

Sistem ekonomi Indonesia, yang berlandaskan pada Pancasila dan UUD 1945sebagai landasan idiil-berorientasi kepada Ketuhanan Yang Maha Esa (berlakunya etika dan moral agama, bukan materialisme); Kemanusiaan Yang Adil dan Beradab (tidak mengenal pada pemerasan dan eksploitasi); Persatuan Indonesia (berlakunya kebersamaan, asas kekeluargaan, sosio-nasionalisme dan sosio-demokrasi dalam ekonomi); Kerakyatan (mengutamakan kehidupan rákyat dan hajat hidup orang banyak); serta Keadilan Sosial (persamaan/emansipasi, kemakmuran masyarakat yang utamabukan kemakmuran bagi seorang). ${ }^{19}$

Dari butir-butir di atas, keadilan merupakan faktor utama dalam sistem ekonomi Indonesia. Keadilan merupakan titik tolak, proses dan sekaligus tujuan negara. Dan sebagai landasan konstitusional guna mewujudkan cita-cita tersebut, pasal 33 UUD 1945 merupakan dasar bagi sistem perekonomian Indonesia yang didukung serta dilengkapi dengan pasal 18, 23, 27 (ayat 2) dan $34 .^{20}$

Dalam banyak uraian mengenai misi pasal 33 UUD 1945 selalu ditekankan bahwa pasal ini berisi politik ekonomi untuk mencapai kemakmuran rakyat. Yang dimaksud dengan kemakmuran ini tidak lain adalah kemampuan pemenuhan kebutuhan dasar. Tetapi dalam upaya peningkatan kemakmuran rakyat sebesar-besarnya, sangat ditekankan peningkatan kemakmuran masyarakat (umum), bukan kemakmuran orang perorang. Perekonomian berdasarkan asas demokrasi ekonomi, kemakmuran bagi semua orang. $^{21}$

${ }^{17}$ M. Dawam Rahardjo, "Ekonomi-Politik Transisi ke Demokrasi di Indonesia" dalam Jurnal Reformasi Ekonomi, Vol. II, No. 1 Januari-April 2001, hal. 18.

${ }^{18}$ Mubyarto, "Beberapa Ciri dan Landasan Pikiran Sistem Ekonomi Pancasila", dalam Sri Edi Swasono (ed), 1998, Sistem Ekonomi dan Demokrasi Ekonomi, Jakarta: UII Press, hal. 145.

${ }^{19}$ Sri Edi Swasono, "Sistem Ekonomi Indonesia", makalah disampaikan dalam seminar Pendalaman Ekonomi Rakyat Sistem Ekonomi Indonesia, Jakarta, 19 Pebruari 2002, hal. 1.

${ }^{20} \mathrm{Ibid}$, hal. 2.

${ }^{21}$ Mubyarto, 1989, "Sistem dan Politik Perekonomian Indonesia", dalam Pelaku dan Politik Ekonomi Indonesia, Yogyakarta: Liberty, hal. 16. 
Menurut Dawam Rahardjo, demokrasi ekonomi di Indonesia ditafsirkan sebagai demokrasi partisipatoris, yang memunculkan dua interpretasi yaitu: pertama, menafsirkan partisipasi ekonomi dengan mewujudkan sistem koperasi yang didefinisikan sebagai kumpulan orang-orang, bukan kumpulan modal, karena sistem yang digerakkan oleh kumpulan modal adalah kapitalisme dan dinilai sebagai sistem ekonomi yang tidak demokratis sebab berdampak pada penyisihan (exclutionary effect) partisipasi sebagian masyarakat dalam segala kegiatan ekonomi. Kedua, demokrasi ekonomi merupakan sistem yang menghimpun kerjasama semua sektor dalam proses pembangunan dan kegiatan perusahaan. Secara kongkret sektor-sektor yang diikutsertakan untuk mendukung sistem ekonomi adalah sektor koperasi, swasta dan negara. ${ }^{22}$

Sektor koperasi membangun ekonomi dari bawah dengan menghimpun orangorang kecil untuk bekerjasama dan saling tolong menolong dalam suasana kekeluargaan antara manusia pribadi, bebas dari penindasan dan paksaan. Menghargai pribadi sebagai makhluk Tuhan dan bertanggungjawab atas keselamatan keluarga dan masyarakatnya, tetapi menolak pertentangan dan persaingan dalam bidang yang sama secara tidak wajar. Karena koperasi merupakan usaha bersama berdasarkan asas kekeluargaan dalam keharmonisan antara kepentingan orang-seorang dengan kepentingan umum. ${ }^{23}$

Pemerintah atau negara bertugas untuk membuat peraturan guna melancarkan jalannya perekonomian, mencegah terjadinya praktek monopolistik, kartel dan trust, menyediakan kebutuhan umum ( public goods) dan bertindak sebagai wasit yang netral dan mengoreksi informasi yang bias dan tidak merata atau memperbaiki pasar yang tidak sempurna (imperfection of market). Peranan negara seperti inilah yang bisa dianggap menjamin berlangsungnya kehidupan demokrasi. ${ }^{24}$

Dalam pada itu negara berkewajiban pula melalui upaya-upaya politik perekonomian dan politik kemakmuran menjamin dan melindungi masyarakat yang miskin dan terlantar (Pasal 34 UUD 1945). Inilah "kewajiban sosial" negara yang ditambah dengan ketentuan pasal 27 ayat 2 -menjamin keseimbangan antara hak setiap warganya untuk pekerjaan dan penghidupan yang layak sesuai dengan harkat dan martabat kemanusiaan-menjadi semacam ukuran berhasil tidaknya negara atau pemerintah dalam menyelenggarkan kesejahteraan sosial seluruh rakyat. ${ }^{25}$

Antara aktivitas koperasi yang bekerja dari bawah dan aktivitas pemerintah yang bekerja dari atas, masih luas bidang ekonomi yang dapat dikerjakan oleh sektor swasta.

${ }^{22}$ M. Dawam Rahardjo, "Ekonomi Politik", hal. 18.

${ }^{23}$ Muhammad Hatta, "Cita-cita Koperasi Dalam Pasal 33 UUD 1945" dalam Sti-Edi Swasono (ed.), 1998, Sistem Ekonomi dan Demokrasi Ekonomi, Jakarta: UI Press, hal. 20.

${ }^{24}$ M. Dawam Rahardjo, "Ekonomi Politik", hal. 16.

${ }^{25}$ Mubyarto, "Sistem dan Politik", hal. 16. 
Pengusaha swasta Indonesia bekerjasama untuk membangun ekonomi nasional bersemangatkan kekeluargaan, ${ }^{26}$ yang segala inisiatif swasta bekerja di bawah pengawasan pemerintah dan dalam bidang dan syarat yang ditentukan pemerintah. ${ }^{27}$ Dengan demikian pemerintah tetap memegang "pimpinan" dalam mengontrol dan mengawasi jalannya perekonomian yang dilaksanakan oleh swasta maupun koperasi (rakyat kecil).

\section{E. Konsep Dasar Kebijakan Ekonomi Indonesia Perspektif Ekonomi Islam}

Untuk mengetahui apakah sistem politik ekonomi Indonesia itu sesuai dengan konsep dasar ekonomi dalam perspektif Islam, terlebih dahulu akan dibahas bagaimana sebenarnya konsep dasar ekonomi dalam Islam.

I. Konsep Dasar Ekonomi Islam

Konsep dasar ekonomi Islam berangkat dari pemahaman secara utuh dan mendalam terhadap filsafat ekonomi Islam. ${ }^{28}$ Karena implikasi dari asas filsafat ini dapat dijadikan sebagai kerangka konstruksi sosial dan tingkah laku sistem, yaitu tentang organisasi kepemilikan, pembatasan tingkah laku individual dan norma pelaku ekonomi. ${ }^{29}$ Nilai-nilai dasar sistem ekonomi Islam merupakan implikasi dari asas filsafat ekonomi tauhid. Adapun nilai-nilai dasar daripada sistem ekonomi Islam adalah sebagai berikut:

Pertama, Nilai dasar kepemilikan. Kekhasan konsep Islam mengenai kepemilikan ini terletak pada kenyataan bahwa dalam Islam, legitimasi kepemilikan itu tergantung pada moral. ${ }^{30}$ Kepemilikan terletak pada memiliki kemanfaatannya dan bukan menguasainya secara mutlak atas sumber-sumber ekonomi, karena kepemilikan harta secara absolut hanya ada pada Allah semata. ${ }^{31}$ Sehingga seorang

${ }^{26}$ Sri-Edi Swasono, "Sistem Ekonomi Kita: Pasal 33 UUD 1945 dan Tantangannya Masa Kini" dalam Sri-Edi Swasono, 1998, Sistem Ekonomi...., hal. 89.

${ }^{27}$ Ibid., hal. 18.

${ }^{28}$ Asas filsafat ekonomi dalam Islam menyatakan bahwa dunia, semua harta dan sumbersumber kekayaan adalah milik Allah, manusia di bumi hanya bertugas sebagai Khalifah, mengelola kekayaan tersebut sebaik mungkin sesuai dengan anjuran-Nya dan Rasul-Nya yang itu semua akan dipertanggungjawabkan di Hari Pengadilan (Kiamat). Lihat M. Nejatullah Siddiqi, 1985, Muslim Economic Thinking: A Survey of Contemporary Literature, Leicester: The Islamic Foundation, hal. 5 .

${ }^{29}$ Ahmad Muflih Saefuddin, 1997, "Perbandingan Sistem Ekonomi Islam dengan Kapitalisme Marxisme" dalam Wawasan Islam dan Ekonomi: Sebuah Bunga Rampai, Jakarta: FE UI, hal. 129.

${ }^{30}$ M. Abdul Mannan, 1997, Teori dan Praktek Ekonomi Islam, ter. Ikhwan Abidin Bisri, Yogyakarta: Dana Bhakti Prima Yasa, hal. 63-64.

${ }^{31}$ Abul Hasan Bani-Sadr, "Islamic Economic: Ownership and Tawhid" dalam John J. Donohue dan John L. Esposito (ed.), 1982, Islam in Transition Muslim Perspectives, New York: Oxford University Press, hal. 230. 
Muslim yang tidak memproduksi manfaat dari sumber-sumber yang diamanatkan Allah padanya akan kehilangan hak atas sumber-sumber tersebut, seperti yang berlaku terhadap pemilikan lahan. Hadis Nabi saw:

$$
\begin{aligned}
& \text { عادى الأرض لله و للرسنول، تم لكم من بعل، فمن أحيا أرضا ميتة فهى له وليسي لمحتجر بعد } \\
& \text { ثلاث سنين. }
\end{aligned}
$$

"Garaplah tanah karena Allah dan Rasul, kemudian itu akan menjadi hakmu. Barang siapa menghidupkan sebidang tanah mati, maka tanah itu menjadi miliknya. Dan tidak berhak memilikinya orang yang sekedar memagarinya dengan tembok setelah tiga tahun"32

Pemilikan terbatas pada sepanjang umurnya selama hidup di dunia dan bila ia mati, maka harta peninggalannya harus didistribusikan kepada ahli warisnya menurut ketentuan Islam, setelah dilakukan kewajiban-kewajiban yang berkenaan dengan si mayit (pemilik harta). ${ }^{33}$ Seperti dalam firman Allah:

$$
\text { كملب عليكم إذا حضر أحدكم الموت إن ترك خحيرا الوصية للوالدين والأتربين بالمعروف حقا }
$$

"Diwajibkan atas kamu, apabila seseorang di antara kamu kedatangan (tanda-tanda) maut, jika ia meninggalkan harta yang banyak untuk berwasiat kepada ibu bapaknya dan karib kerabat secara ma'ruf, (ini adalah) kewajiban atas orang-orang yang bertakwa"34

Tidak diperbolehkan kepemilikan secara perseorangan terhadap sumbersumber yang menyangkut kepentingan umum dan sumber-sumber alam yang menyangkut hajat hidup orang banyak. Sumber-sumber ini menjadi milik umum atau negara. ${ }^{35}$ Hadis Nabi saw:

$$
\text { المسلدون شر كاء فن ثلاثث: الماء و الكاءلاء و النار. }
$$

"Semua orang Islam berserikat dalam tiga hal: dalam hal air, rumput, api." (HR. Ahmad dan Abu Daud) ${ }^{36}$

${ }^{32}$ Sayyid Sabiq, 1983, Fiqh Sunnah, Jilid III, Beirut; Dar al-Kutub, hal. 195.

${ }^{33}$ Abul Hasan Bani-Sadr, "Islamic Economics...", hal. 233-234.

${ }^{34}$ Q.S. 2:180.

${ }^{35}$ M. Nejatullah Siddiqi, Muslim Economic.., hal. 9.

${ }^{36}$ Sidqî Muhammad Jamîl, 1994, Sunan Abî Dawud lil Hâfiz Abî Dawud Sulaimân Ibn alAsh'ath al-Sajastani, Beirut: Dâr al-Fikr, hal. 258. 
Empat macam barang ini juga dapat dikiaskan kepada barang tambang dan minyak bumi serta kebutuhan-kebutuhan pokok manusia pada waktu dan kondisi tertentu. Dalam kategori milik umum ini termasuk sumber-sumber air minum, hutan, laut dan isinya, serta udara dan ruang angkasa.

Kedua, Keseimbangan. Merupakan nilai dasar yang pengaruhnya terlihat pada berbagai aspek tingkah laku ekonomi muslim, misalnya kesederhanaan (moderation), hemat (parsimomy) dan menjauhi sifat pemborosan (extravagance).

Konsep kesederhanaan ini tidak hanya berupa timbangan kebajikan hasil dari usahanya yang diarahkan untuk dunia dan akhirat saja, tetapi juga berkaitan dengan keseimbangan antara kepentingan kebebasan perseorangan dengan kepentingan umum, serta keseimbangan antara hak dan kewajiban. Seperti yang difirmankan Allah berikut:

$$
\text { ومنهم من يقول ربنا أعنا في الدنيا حسنة و فن الأخرة حسنة وقنا عذابب النار. }
$$

"Dan di antara mereka ada orang yang berdoa: "Ya Tuhan kami, berilah kami kebahagiaan di dunia dan kebaikan di akhirat dan peliharalah kami dari siksa api neraka"37

Konsep nilai kesederhanaan berlaku dalam tingkah laku ekonomi terutama dalam menjauhi sifat konsumtif. ${ }^{38}$ Menjauhi pemborosan berlaku tidak hanya untuk pembelanjaan yang diharamkan tetapi juga pembelanjaan dan sedekah yang berlebihan. ${ }^{39}$ Apabila suatu waktu keseimbangan ini terganggu dan terjadi ketimpangan-ketimpangan sosial ekonomi dalam kehidupan masyarakat, maka haruslah ada tindakan-tindakan untuk mengembalikan ke keseimbangan semula.

Berbagai ujian di dunia ini, seperti kelaparan, kemiskinan, sempitnya lapangan pekerjaan dan lain-lain, mengakibatkan keseimbangan terganggu, kestabilan dan keamanan pun terganggu. Dalam keadaan demikian Islam telah menggariskan suatu aturan untuk mengadakan distribusi kekayaan dengan mengambil dari yang kaya dan menyalurkan kepada yang miskin dengan pembagian zakat, sedekah, hibah dan waris. ${ }^{40}$ Kemungkinan tindakan lain misalnya nasionalisasi industri atau kegiatan ekonomi lain yang dapat mengimplikasikan nilai dasar keseimbangan.

${ }^{37}$ Q.S. 2:201.

${ }^{38}$ Q.S. 7:31.

${ }^{39}$ Q.S. 17:29; 55: 8-9.

${ }^{40}$ Dengan ketetapan syariah yang terwujud dalam kewajiban membayar zakat-apabila telah satu nisab dan satu haul-waris, sedekah dan hibah memberikan suatu jaminan terhadap "pembagian dan penyebaran secara terus menerus" akan harta benda. Lihat Afzalur Rahman, 1995, Doktrin Ekonomi Islam, ter. Nastangin dan Soeroyo, Jilid II, Yogyakarta: Dana Bhakti Wakaf, hal. 110-111. 
Ketiga, Keadilan Sosial. Al-Qur'an merujuk pada konsep keadilan yang merupakan istilah ketiga di antara istilah-istilah yang paling sering digunakan setelah "Allah" dan "Ilmu Pengetahuan". ${ }^{41}$ Boleh jadi keadilan dianggap sebagai konsep yang lebih luas dimana keadilan sosial memperoleh kedudukan utama. Dalam kenyataannya, banyak penulis kontemporer menegaskan bahwa keseluruhan infrastruktur hukum di dalam Islam di dasarkan pada keadilan sosial. ${ }^{42}$

Konsep keadilan sosial, sebagaimana yang sering dibahas oleh pemikir-pemikir kontemporer itu bersifat multidimensional. Keadilan berkaitan dengan dan berintikan kebenaran ( $a l-h a q),{ }^{43}$ persamaan di hadapan hukum, dijaminnya persamaan di dalam pendidikan-yang merupakan tanggungjawab negara; dilaksanakannya pajak kekayaan untuk penyediaan kebutuhan dasar bagi mereka yang tidak beruntung dalam rangka mengurangi kesenjangan ekonomi. ${ }^{44}$ Keadilan berarti pula kebijaksanaar dalam mengalokasikan sejumlah hasil tertentu dari kegiatan ekonomi bagi mereka yang tidak mampu memasuki pasar atau tidak sanggup membelinya menurut kekuatan pasar, yaitu kebijaksanaan melalui zakat, infaq dan sedekah. ${ }^{\dot{4}}$

Demikianlah nilai-nilai dasar dari sistem ekonomi dalam perspektif Islam yaitu kebebasan terbatas terhadap kepemilikan harta dan sumber-sumber kekayaan, nilai keseimbangan dan nilai keadilan yang merupakan kebulatan nilai yang tidak bisa dipisahkan. Pangkal tolak nilai dasar ini, kemudian melahirkan nilai-nilai instrumen yang terealisasi dalam pelarangan riba, diperintahkannya zakat, sedekah dan infaq.

2. Keselarasan Sistem Ekonomi Indonesia dengan Konsep Dasar Ekonomi Islam

Dari penjelasan terdahulu tentang sistem (politik) ekonomi Indonesia dapat diketahui bahwa sistem ekonomi yang dapat dijadikan landasan, berpijak pada unsur keagamaan (religiusitas). ${ }^{46}$ Pancasila sebagai ideologi negara pun telah

${ }^{41} \mathrm{Hal}$ ini pernah dikemukakan oleh Syekh N.H. Naqvi, 1986, Ethics and Economics: An Islamic Synthesis, Leicester: The Islamic Foundation, hal. 86.

${ }^{42}$ Shahrukh Rafi Khan, 2002, "Sistem Ekonomi Politik dalam Negara Islam" dalam Jurnal Millah, Vol., II, No. 1 Januari, hal. 31.

${ }^{43}$ M. Dawam Rahardjo, 1994, "Adl" dalam Jurnal Ulumul Qur 'an, Vol V, No. 3, hal. 47.

${ }^{44}$ Shahrukh Rafi Khan, "Sistem Ekonomi Politik", hal. 30; Lihat juga M. Umer Chapra, 2000, Masa Depan Ekonomi Islam, ter. Ikhwan Abidin Bisri, Yogyakarta: Dana Bhakti Wakaf, hal. 132. ${ }^{45}$ Lihat Q.S. 2:1 10,271, 280.

${ }^{46}$ Menurut Bung Hatta alasan mengapa landasan ekonomi Indonesia bernafaskan keagamaan lebih dikarenakan adanya dorongan etika agama untuk saling membantu dan bekerjasama (asas kekeluargaan). Melaksanakan kerajaan Allah di atas dunia adalah tujuan. Kemudian perasaan keadilan menggerakkan jiwa untuk berontak dari kesengsaraan hidup dalam masyarakat terhadap perbedaan yang mencolok antara si kaya dan si miskin. Lithat Sri-Edi Swasono, 1998, "Ekonomi Indonesia: Sosialisme Religius" dalam Sistem Ekonomi dan Demokrasi Ekonomi, Jakarta: UI Press, hal. 138-139. 
mencantumkan Ketuhanan Yang Maha Esa sebagai sila pertamanya. Sedangkan Pasal 29 UUD 1945 dengan tegas pula menyatakan bahwa negara berdasar atas asas Ketuhanari Yang Maha Esa.

Memang ada yang mengemukakan bahwa ilmu ekonomi dengan teoriteorinya yang bersifat universal, maka tentunya ada tempat bagi suatu bangsa yang ideologi resminya tidak mengakui adanya Tuhan, untuk mengembangkan sistem ekonomi yang dianggap cocok untuk bangsanya. Di pihak lain ada juga bangsa yang menganggap ilmu ekonomi itu bebas nilai, sehingga sistem ekonomi yang dikembangkan lepas dari penghidupan pribadi anggota-anggota warga bangsa tersebut. Agama menurut kepercayaan bangsa ini bersifat pribadi sehingga tidak perlu mengaitkannya kepada sistem ekonomi.

Bagi bangsa Indonesia, pemikiran tersebut di atas tidak dapat diterapkan di negara ini, selain bertentangan dengan cita-cita para pendiri bangsa, juga tidak sesuai dengan semangat ideologi Pancasila. Di Indonesia, yang eksistensi dan hak hidup beberapa agama besar diakui (Pasal 29 UUD 1945), nilai-nilai yang dikembangkan berasal dari berbagai agama, termasuk nilai-nilai adat asli bangsa Indonesia yang berasal dari berbagai:suku bangsa. Dalam pada itu, karena mayoritas penduduk Indonesia beragama Islam, nampaknya paling besar pengaruhnya dalam mempengaruhi aturan main nilai-nilainya, termasuk di dalamnya nilai-nilai ekonominya. $^{47}$

Sistem ekonomi Islam yang dijiwai oleh konsep-konsep ajaran tauhid, memang dapat diamati bisa berjalan di sebagian masyarakat yang mayoritas beragama Islam. Namun dalam perkembangan ekonomi yang mengglobal dengan persaingan terbuka, terkadang memaksa mereka untuk menerapkan praktekpraktek bisnis yang non Islami. Misalnya perusahaan yang berbentuk perseroan terbatas yang memisahkan kepemilikan dan pengelolaan, dalam proses meningkatkan modal melalui pasar modal, sering terpaksa menerima asas-asas sistem ekonomi kapitalis yang tidak Islami..$^{48}$

Merujuk pada sila pertama, Ketuhanan Yang Maha Esa, sistem ekonomi Indonesia menekankan pada moral Pancasila yang menjunjung tinggi asas keadilan ekonomi dan keadilan sosial seperti halnya sistem ekonomi Islam. Tujuan sistem. ekonomi Pancasila maupun sistem ekonomi Islam adalah keadilan sosial bagi seluruh rakyat Indonesia yang diwujudkan melalui dasar-dasar kemanusiaan dengan caracara yang rasionalistik dan demokratis.

${ }^{48}$ Mubyarto, 2002, "Penerapan Ajaran Ekonomi Islam di Indonesia" dalam Shari'ah Economics Days, Jakarta: Forum Studi Islam Senat Mahasiswa FE-UI, hal. 1. 
Demikian pula ketika melihat kembali kepada adanya larangan terhadap kepemilikan sumber-sumber umum, yang mengenai hajat hidup orang banyak dimiliki oleh orang-seorang (Pasal 33 UUD 1945). Hal ini tentu sejalan dengan apa yang digariskan dalam sistem ekonomi Islam yang tidak menghendaki adanya monopoli satu orang terhadap sumber-sumber yang menyangkut hajat hidup orang banyak. Karena sumber-sumber umum ini hanya boleh dikuasai oleh pemerintah.

\section{F. Penutup}

Berangkat dari paparan di atas bisa dikemukakan, bahwa secara konseptual pada dasarnya ekonomi Pancasila memiliki banyak persamaan dengan konsep dasar ekonomi Islam. Sisi kesamaan ini terutama terletak pada tujuan akhir ekonomi Pancasila yang bertujuan untuk memperoleh keadilan sosial bagi seluruh Indonesia. Pesan keadilan sosial ini jugalah yang merupakan inti dan semangat yang melandasi ekonomi Islam. Meski secara konseptual ekonomi Indonesia memiliki tujuan yang luhur, namun karena perkembangan ekonomi sangat terkait dengan kebijakan (politik) suatu pemerintahan, maka dalam prakteknya pada setiap masa pemerintahan sistem ekonomi Indonesia ini memiliki wajah yang beragam. Adanya keragaman ini, kiranya dapat menjadi pelajaran berharga bagi setiap orde pemerintahan dalam perumusan suatu kebijakan yang sedapat mungkin bisa merujuk pada cita-cita mulia dari sistem ekonomi Indonesia itu sendiri.

\section{DAFTAR PUSTAKA}

Aminuddin, 1999, Kekuatan Islam dan Pergulatan Kekuasaan di Indonesia Sebelum dan Sesudah Runtuhnya Rezim Soeharto, Yogyakarta: Pustaka Pelajar.

Chapra, M. Umer, 2000, Masa Depan Ekonomi Islam, ter. Ikhwan Abidin Bisri, Yogyakarta: Dana Bhakti Wakaf.

Donohue, John J, dan John L. Esposito (ed.), 1982, Islam in Transition Muslim Perspectives, New York: Oxford University Press.

Emmerson, Donald K. (ed.), 2001, Indonesia Beyond Soeharto: Polity Economy Society Transition, New York: ME. Sharpe.

Hill, Hal, 2001, Ekonomi Indonesia, ter. Tri Wibowo Budi Santoso, Jakarta: - Rajagrafindo Persada. 
Isjwara, F., 1989, Pengantar lmu Politik, Semarang: Putra Bardin.

Jamîl, Sidqî Muhammad, 1994, Sunan Abî Dawud lil Hâfiz Abî Dawud Sulaimân Ibn al-Ash'ath al-Sajastanî, Beirut: Dâr al-Fikr.

Kasiyanto, M.J., 1999, Masalah Sospol Dalam Pembangunan, Kharismatik, Fundamentalis, Revolusi Gagal Membangun, Jakarta: Tri Mawar.

Khan, Shahrukh Rafi, 2002, "Sistem Ekonomi Politik dalam Negara Islam" dalam Jurnal Millah, Vol. II, No. I Januari.

Mannan, M. Abdul, 1997, Teori dan Praktek Ekonomi Islam, ter. Ikhwan Abidin Bisri, Yogyakarta: Dana Bhakti Prima Yasa.

Mas'oed, Mochtar, 1989, Ekonomi dan Struktur Politik Orde Baru 1966-1971, Jakarta: LP3ES.

---_--, 1994, Ekonomi Politik Internasional dan Pembangunan, Yogyakarta: Pustaka Pelajar.

Mubyarto, 1989, "Sistem dan Politik Perekonomian Indonesia", dalam Pelaku dan Politik Ekonomi Indonesia, Yogyakarta: Liberty.

------, 2002, "Penerapan Ajaran Ekonomi Islam di Indonesia" dalam Shari'ah Economics Days, Jakarta: Forum Studi Islam Senat Mahasiswa FE-UI.

Naqvi, Syekh N.H., 1986, Ethics and Economics: An Islamic Synthesis, Leicester: The Islamic Foundation.

Rahardjo, M. Dawam, 1994, “Adl” dalam Jurnal Ulumul Qur'an, Vol V, No. 3.

------, 2001, "Peran Negara dalam Proses Demokrasi Ekonomi" dalam Jurnal Reformasi Ekonomi, No. I Januari-April.

-.---, 2001, "Ekonomi-Politik Transisi ke Demokrasi di Indonesia" dalam Jurnal Reformasi Ekonomi, Vol. II, No. 1 Januari-April. 
Rahman, Afzalur, 1995, Doktrin Ekonomi Islam, ter. Nastangin dan Soeroyo, Jilid II, Yogyakarta: Dana Bhakti Wakaf.

Sabiq, Sayyid, 1983, Figh Sunnah, Jilid III, Beirut; Dar al-Kutub.

Saefuddin, Ahmad Muflih, 1997, "Perbandingan Sistem Ekonomi Islam dengan Kapitalisme Marxisme" dalam Wawasan Islam dan Ekonomi: Sebuah Bunga Rampai, Jakarta: FE UI.

Siddiqi, M. Nejatullah, 1985, Muslim Economic Thinking: A Survey of Contemporary Literature, Leicester: The Islamic Foundation.

Soule,George, 1994, Pemikiran Para Pakar Ekonomi Terkemuka dari Aristoteles Hingga Keynes, terj. Gilarso, Yogyakarta: Kanisius.

Swasono, Sri Edi, 2002, "Sistem Ekonomi Indonesia", makalah disampaikan dalam seminar Pendalaman Ekonomi Rakyat Sistem ekonomi Indonesia, Jakarta, 19 Pebruari.

(ed.), 1998, Sistem Ekonomi dan Demokrasi Ekonomi, Jakarta: UI Press.

Undang-Undang Dasar Republik Indonesia Tahun 1945, 2002, Bandung: Citra Umbara. 